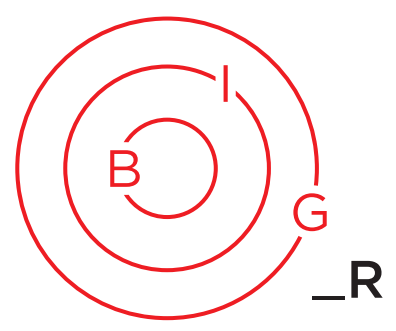

\section{ART FEATURE}
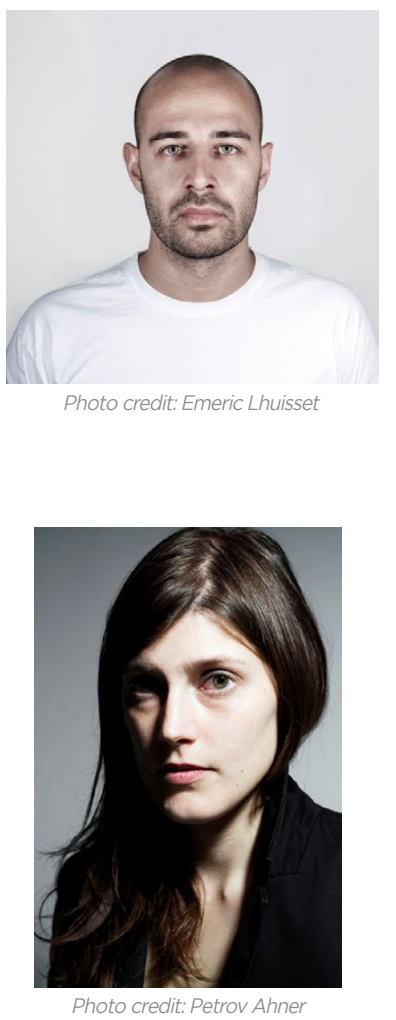

Borders in Globalization Review

Volume 2, Issue 2 (Spring/Summer 2021): 141-148

https://doi.org/10.18357/bigr22202120218

\section{Borders \& Personal Mythologies: An Interview with Emeric Lhuisset}

\section{By Elisa Ganivet}

On February 18, 2021, Elisa Ganivet interviewed the photographer Emeric Lhuisset, known for his immersion in conflict zones. Discussing his art projects, the conversation cross-examined the concepts of border and territory in visual art. Portions of the interview are reproduced here, in English translation from the original French, alongside photos of the artist's work. (The Frenchlanguage version will be published in the next issue of BIG_Review.)

\section{Biographies}

Emeric Lhuisset, born in 1983, grew up in Paris suburbs. He graduated from the Beaux-Arts de Paris and in geopolitics from University Panthéon-Sorbonne and Ecole Normale Superieure Ulm. His works has been shown in numerous exhibitions around the world (Tate Modern, Museum Folkwang, Institut du monde arabe, Stedelijk Museum, Rencontres d'Arles, Sursock Museum, Musée du Louvre Lens...). In addition to his art practice, he teaches at Sciences Po about contemporary art \& geopolitics. www.emericlhuisset.com

Elisa Ganivet, born in 1982, is a doctor of philosophy, art historian and curator. Her research in aesthetics explores the mechanisms of utopian practices and border concepts, especially geopolitical walls. She has been published by Columbia University Press, Trancript Verlag, Presses de l'Université du Québec, Presses du Réel, and BIG_Review. She has been guest Researcher at La Sorbonne and Casa de Velazquez. She works as a consultant for international public and private cultural organizations. Begining in fall 2021, she will be Visual Art Editor for BIG_Review. www.elisaganivet.com 


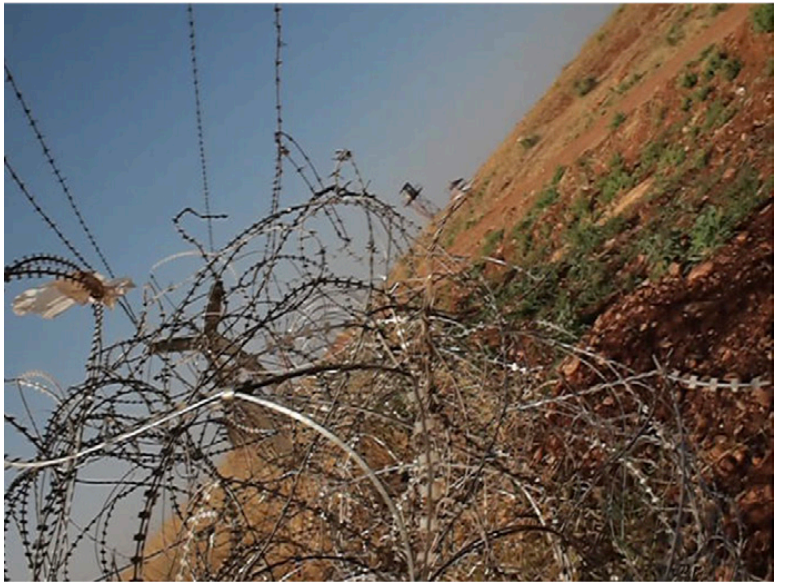

(c) Emeric Lhuisset, Border crossing Syria-Turkey, video still, 2010-2018. Courtesy the artist.

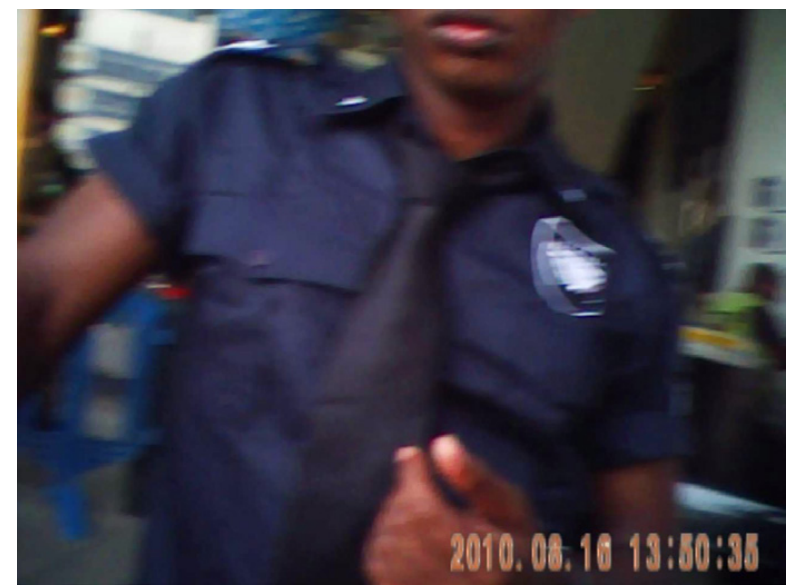

(c) Emeric Lhuisset, Travel, personal archive photo, 2010. Courtesy the artist.

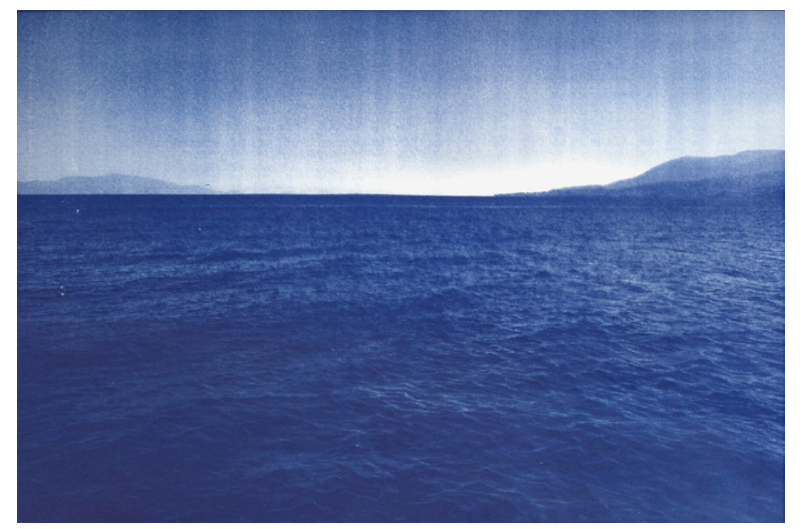

(c) Emeric Lhuisset, L'autre rive, Iraq, Syria, Turkey, Greece, Germany, Denmark, France, 2011 - 2017. Courtesy the artist.
EG: Emeric, you are an internationally recognized artist for your fieldwork in conflict zones, mainly in the Middle East, as well as in Ukraine, Colombia... Photography is your favorite tool and we discover others over the years. When we first talked about the notion of the border, your first remark was to underline the fact that war and borders were inextricably linked. In your body of work, are there any explicit references to this idea, to this feeling of the border? I'm thinking in particular of your film When the clouds speak where at the end we follow you, on a hand-held camera, in one of your clandestine crossings, one of the many you made between Syria and Turkey. Is this video part of a spontaneous practice or is it part of a vision to regroup them later?

EL: Not especially, but l've always been interested in this idea of borders, both state borders and borders within a state. For example, on the Israeli territory (without even mentioning the Palestinian one), there are places that are completely divided. You enter a hangar to take a bus and you are controlled as if you were in an airport, where you will go through portals, scanners, etc. At the entrance of a market, there are barriers and your bags are searched before entering. In France, this is now almost normal but it was not at all normal at the time (2010). When I worked in Iraq, Afghanistan, Syria, Turkey or even Colombia, I passed through many checkpoints which is always quite heavy, complicated. You never know if you'll make it through, sometimes you don't have the authorization to access certain parts of the territory, you have to try to trick them, it can be very oppressive. In Pakistan, it's the same, there are checkpoints to go to the tribal areas where normally a classic visa is not enough. In Iraq, I had to go through checkpoints to enter the Arab zones, whereas I only had a visa for the Kurdish zones. So it is not necessarily a question of purely state borders but of a fragmentation of spaces. This feeling has always impacted me. There is also the case of borders that we do not really see. It is the case in the Amazonian forest for example where one crosses from Colombia to Brazil without noticing it. This caused me some troubles.

These videos made between Syria and Turkey are personal archives. I regularly document my projects, but these archives were not intended to be shown. I finally decided to include this sequence of the passage from Syria to Turkey in a more global project (2010-2018) on refugees. I was interested in the precise moment when people fleeing the war in Syria cross the barbed wire that separates these two states, the precise moment when they physically become refugees. It is an instant. A few centimeters before, they are not yet, a few centimeters after, they are.

It was interesting to include this sequence in this project, because I speak first of all about the time before "being a refugee", about the destiny of people who have become or could have become refugees. I also talk about the crossing, the crossing of the sea, the 
Borders in Globalization Review | Volume 2 | Issue 2 | Spring/Summer 2021 Ganivet, "Borders \& Personal Mythologies: An Interview with Emeric Lhuisset"
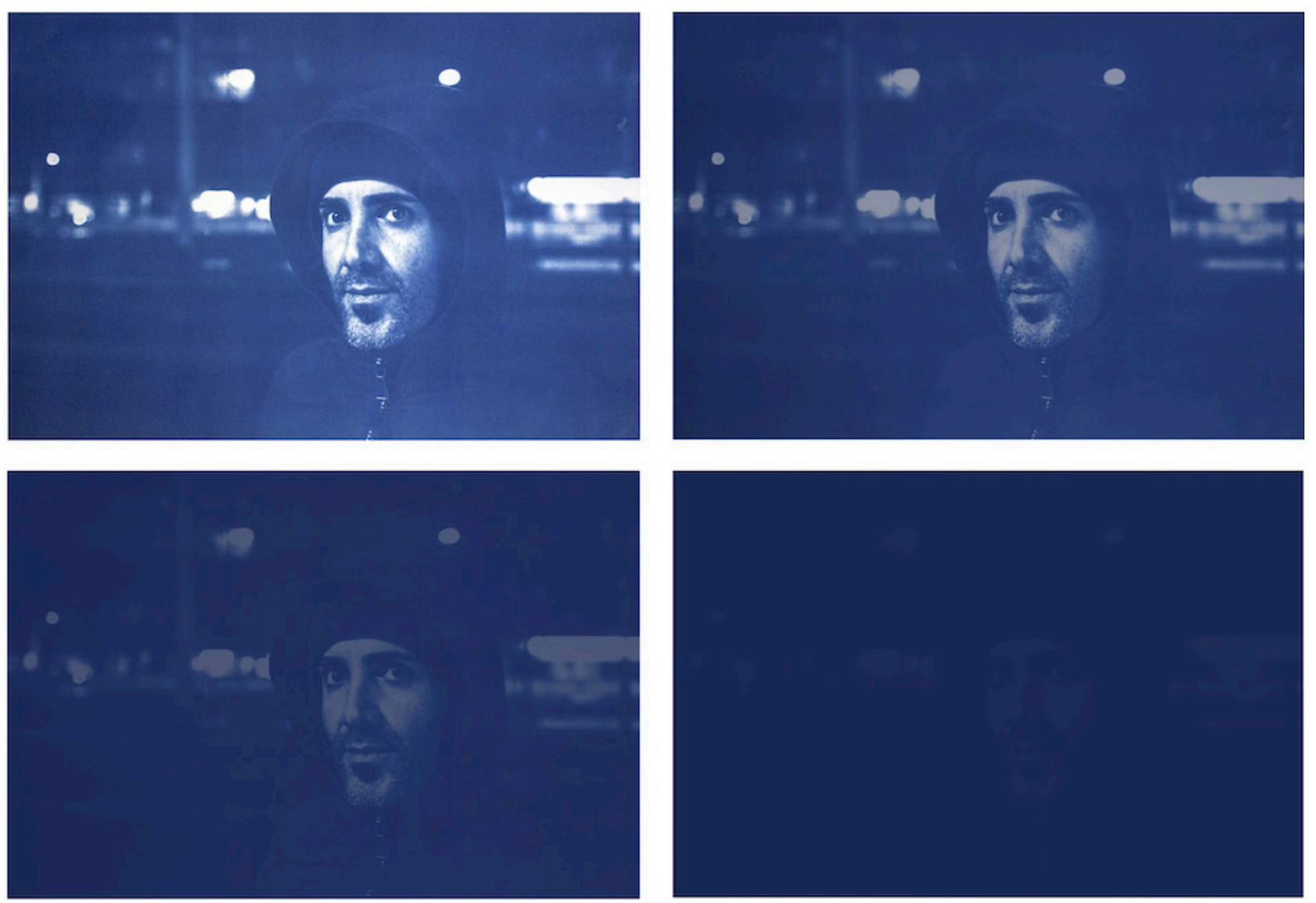

c) Emeric Lhuisset, L'autre rive, Iraq, Syria, Turkey, Greece, Germany, Denmark, France, 2011 - 2017. Courtesy the artist.

crossing of Europe, then the arrival to a territory where they will settle. With the project L'autre Rive (The other shore), what interests me is to talk about these friends I met in Iraq or Syria, whom I found again eight years later in Europe and who have become refugees. But this is not the first time that I reuse personal archives. I had already done so in my book entitled Souvenirs de Syrie (Souvenirs from Syria).

While I was living with Syrian rebel fighters, hidden in a cave in the mountains, I had taken some photographs of this very strange daily life. A daily life made of bombings, shootings but also of waiting and tension. I wanted to document it for my own archives. It was a year later, when I was looking at these images again because one of my friends had been killed and I wanted to see him again, that I said to myself that I had to show them because they were important, they testified to a reality ignored by many. But the question was how to show them. They were not works that I had thought of as such. Moreover, these images were sometimes very hard, quite violent with tortured people, houses just after a bombing, with the atrocities that go with it... For me, hanging these images on a wall doesn't make sense, it would be obscene. So I thought at one point of giving them to the press.

EG: But this goes against your artistic approach.
EL: The idea was to make these images visible, this daily life. It seemed important to me to bear witness. If the press got hold of them, I had to know how to choose the modalities. But these images were a year old, they were already too old, which made me wonder about the obsolescence of the journalistic image. Even an image from a week ago seems outdated. This dimension is a bit absurd because a man shooting from his window in a city in Syria, whether it was taken two days ago or five years ago, is still the same thing to illustrate an article. It's a bit absurd to want the freshest, most instantaneous photograph possible. So since it was impossible for me to use these "archives" with the media, the question was what I could do with them. Can we talk about a memory of a war when it is still going on? This did not seem appropriate to me either. I finally decided to make a black book without text, like a black box, a family album: Memories of Syria. These photographs exist only in this book.

EG: What you question in the daily life of conflict zones is also the moments of waiting, of boredom, of anguish. You transcribe these wars by erasing any sensational effect, of sensationalism. In this dynamic of understanding the mechanism of the war, of its staging, its construction, of being in front, behind, around, the environment, the territory. You manage to define the mechanisms and to bring out a respect as well. One 
perceives the respect towards the fighter and towards the image. This is possible thanks to your consistency over the long term, creating bonds of trust and friendship. In your project When the clouds speak at the very end appears this illegal crossing from Turkey to Syria. Personally, this touched me enormously because this excerpt gives an incredible scope to the work. In the dedication we see the portrait of one of your friends who disappeared while trying to cross a border. You pay tribute to him. This revealed that sincere experience is something we rarely see in the whole of the artistic production which treats, closely or by far, our themes.

EL: I chose to put this video clip at the end of this film because it makes particular sense with the issue of the Kurds. The Kurdish territory is larger than that of the Turkish state itself. The Kurds are in several states. This is or was also the case with the Armenians and the Assyrians, whom I also talk about. These are different peoples existing on this vast territory but also beyond the borders of this territory, they are peoples who transgress this notion of state border. On the other hand, I also wanted to end with this video because my friend Hamidreza died on the borderline between Turkey and
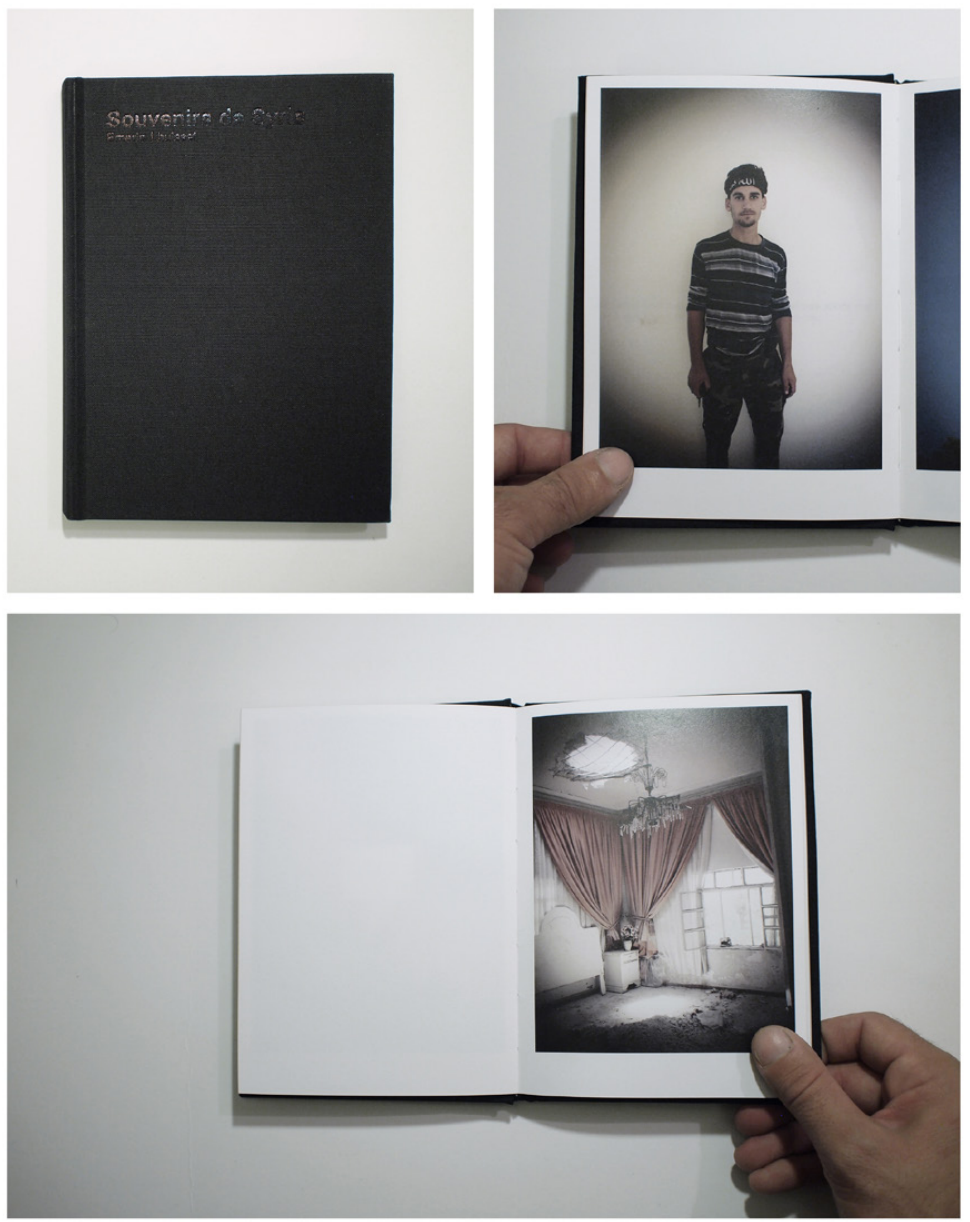

(c) Emeric Lhuisset, Souvenirs de Syrie, Alep and Idlib province (Syria) June and August 2012 - book realized in 2013. Courtesy the artist.
Iraq during a bombing by the Turkish air force. I wanted to dedicate this film to him because he was someone who had helped me a lot, especially for the series Théâtre de guerre (Theater of war) and to whom I was close. At a certain point, I had no more news and did not understand why until friends told me that he had died. This border crossing also reflects this story.

EG: The concept of a border is completely ambivalent. Even geographers have difficulty agreeing on a common definition. One can evoke a line, which restricts to the cartographic tool, originally military. One also speaks of a network, a mesh, which is undoubtedly more relevant when one touches the border.

EL: It is also a zone of tension.

EG: Yes, of course. In this regard, the geographer Claude Raffestin describes the border as a cut, one that constrains the individual because of controls, the security measures and the reinforcement of the infrastructure. We think of a cut, like a breach between two worlds.

EL: I have not theorized the notion of the border but yes, I think I can say that it is what separates. These are populations, communities, which through the creation of a state and borders, have decided not to live with others who are next door. Basically, the idea of the frontier is hyperviolent, if we analyze it from that point of view.

EG: Raffestin also says that the border is a seam, when we consider the social, societal and economic flows and interdependencies...

EL: A seam, or rather I see it as a suture, because it is two elements that have been together and then torn apart. We create bridges from this.

EG:This is also another image. We often speak of Borders-bridges and Borders-walls. When one lives the territory, one realizes this.

EL: Yes, the wound to be healed on one side and the wound left open on the other. If we stay in the metaphor [laughs]. I realize that I've never had very good experiences with borders. It's definitely an element of tension that l've felt. Without even looking at signs announcing them, you know it when you get close. The military is usually more heavily armed, even helmeted, whereas elsewhere they are not etc.

EG:But we ourselves, when we were children, before the Schengen agreements of 1992, experienced this kind of tension at the border crossing. 
EL: Yes, that's right. I remember anecdotes about this when I was going to Germany with my grandmother. Once, on the train, she told me not to worry about the French customs officers. And indeed, they were nice and let us pass, with their visors raised a bit coolly. But she had told me that the Germans were less friendly. And I remember German customs officers who didn't smile at all and wore their uniforms in a very strict mode. I don't know if it was a flashback to World War II for her or the fact that we had to show our papers, but she was very stressed about crossing the border. Today it seems so far away, even absurd. Thanks to the near erasure of borders in the European Union, we have arrived at something very pleasant. But during my work in 2016 on refugees, while passing from Germany to Denmark, I was shocked by the Danes who had set up a checkpoint at the border. So, in order to document this, I took photographs with them, pretending to be an idiot tourist so that they wouldn't be suspicious.

EG: It's that we are currently living with the withdrawal of the border because of Covid..

EL: Yes, we are on what I hope is a parenthesis.

EG: On the other hand, you refer to a methodology, that of the usefulness of playing the idiot tourist in order to document these particular situations. But can you explain your approach when you travel to territories such as Iraq, Syria, Afghanistan...

EL: In this case, I make very few images. My approach is completely different in conflict zones. First, I meet people and talk to them about my work. It can take years to get these kinds of images because they are based on relationships of trust. It took me three years to make the series Theater of War which includes fourteen images. Over time, you can't lie to people. They realize who you are. I didn't try to lie to them, I just told them what I was doing, what interested me, what I wanted to say. We talked, we built the project together. And it is really this approach that interests me in the sense that when I arrive, it is with my culture, my baggage, with all this personal mythology as Roland Barthes would say. The people I am going to meet also have theirs. So we are going to confront these views, not in a confrontation but in an exchange. We will reflect and build the project together. My ideas, my culture do not necessarily make sense to them. When I make a work it is not there or here. This work must be as relevant there as it is here. For me it is essential. That's why I also exhibit a lot in the Middle East. I try to show my work

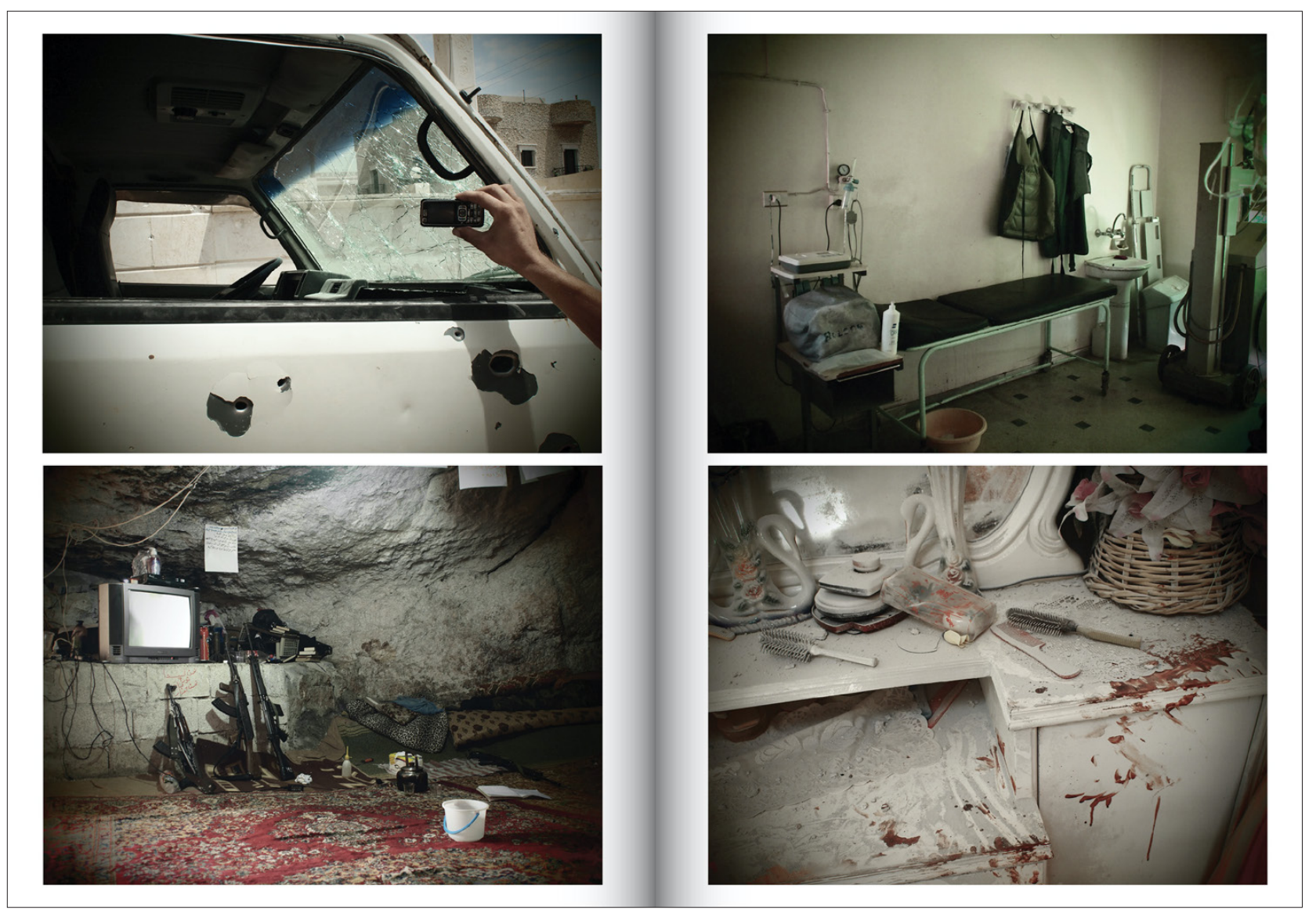

(c) Emeric Lhuisset, Souvenirs de Syrie, Alep and Idlib province (Syria) June and August 2012 - book realized in 2013. Courtesy the artist. 
Borders in Globalization Review | Volume 2 | Issue 2 | Spring/Summer 2021

Ganivet, "Borders \& Personal Mythologies: An Interview with Emeric Lhuisset"

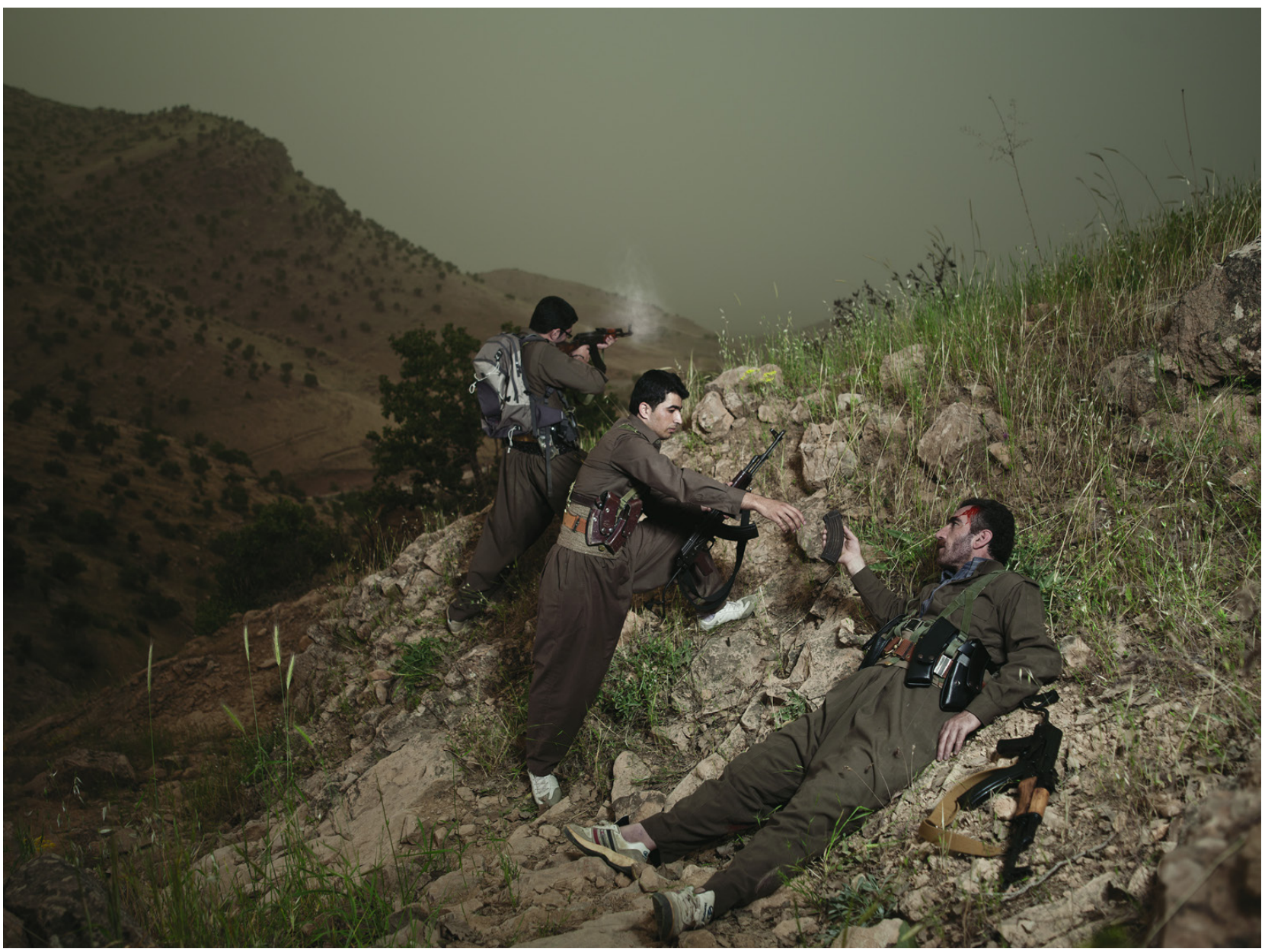

(c) Emeric Lhuisset, Théâtre de guerre, photographs with a group of Kurdish guerrilla, Iraq, 2011-2012. Courtesy the artist.

there too and not just do it there. I deal with subjects that are quite far away from me because I need to have enough distance from my subject to be able to deal with it. It is very difficult for me to deal with subjects that I am too close to. Indeed, I feel that I don't have the necessary distance to be able to treat them in an objective way. It is a bias to deal with subjects that are not directly related to myself. For example, I grew up in the suburbs of Paris and I have often been asked why I don't work on this subject. But I don't want to work on it because I lack the necessary distance and objectivity. I have this need to have a distance on my subjects.

EG: But currently, with our travel restrictions due to the pandemic, you are developing a project for which you will go to people's homes.

EL: Yes, but it is finally usual in my work. For example, when I work with armed groups, we are also intimate. Or with the refugees, it's the same sharing, I went to meet them, to follow them as a friend. That's what allowed me to make these kinds of images. I spent time with friends in fact. I documented these moments spent together.

EG: But this is in France.
EL: My work with refugees took place in Germany and Denmark, and for the second generation, in France with friends who had a refugee parent. I worked with Ines whose father had left Algeria, with Sarah whose father had left Saddam Hussain's Iraq, just like my cousin's father, my uncle. I was in the family [laughs]. I work a lot in and with intimacy. I like to understand people. The approach is anthropological, even psychoanalytical. It's about the people themselves, about what they think. I became aware of this dimension late in life. Throughout my schooling at the Beaux-Arts, I took courses in art psychoanalysis with Christian Gaillard. I studied Jung, Freud etc. which certainly influenced me because instinctively, I asked people if such and such a thing did not refer them to such and such. In the field, I proceed in the same way. At the beginning, when you work with guerrilla groups, they will give you the propaganda speech of the group. There is nothing negative about that, it's just the image they want to give. To get beyond that, the psychoanalytical dimension is welcome. It is a question of understanding the individual, the reasons that brought him to this situation, and where he wants to go. Apart from any discourse, what is it that really interests him? And we come back to: "Oh yes, but when I was a kid..." It's fascinating because it's often linked. 
EG: You also have to find common psychological traits between each fighter. On both sides your approach to understanding the person is the same...

EL: Yes, to better understand the profile of the fighters I will work with is a fundamental step. We surrender to each other, which in war zones is not without risk. My life is somewhat in their hands. When you are with a guerrilla group in a cave in Syria, your life is not worth much, or on the contrary, it is. You have to build mutual trust. When the fighters let me make images, they give themselves to me too. It's very important to understand the people you are giving yourself to. Within the group, within the community, knowing who you can trust more or less. To understand all the mechanisms both for the project, for my own security, but also simply for human interest. I often try to understand people whose ideology is the opposite of mine. I try to understand the mechanisms of their thinking with which I personally do not agree, and by grasping them, how I can deconstruct them. In particular with regard to the way refugees are looked at, people can have prejudices that seem hateful towards them. If you look deeper, you will see that it is rarely hate. In fact, hate as such is very rare. It is more about misunderstanding and fear. Misunderstanding leads to fear, which in turn leads to a very violent discourse. So, if we stop at the first glance that looks like hate, the rest of the approach will be wrong and we will not succeed in deconstructing the looks.

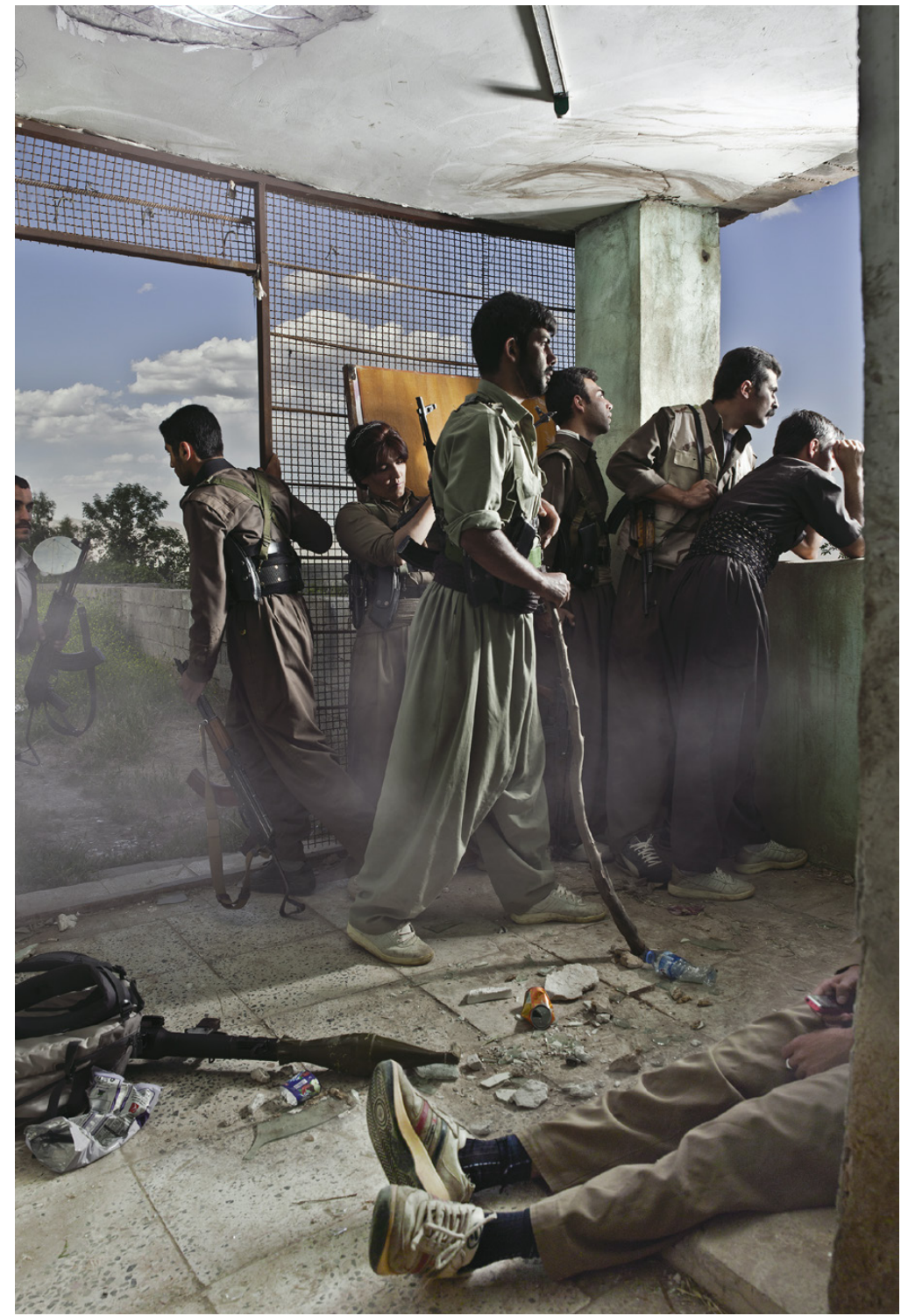

(c) Emeric Lhuisset, Théâtre de guerre, photographs with a group of Kurdish guerrilla, Iraq, 2011-2012. Courtesy the artist.
EG: Why do you want to deconstruct this type of look?

EL: Because I believe that some of them are unjust, that they create violence, a danger both for the people against whom they stand and for society as a whole. Many people with this a priori hateful look will share it, will set up leaders who will decide according to that. In this way, we arrive at totalitarian societies, at the absurdities that man has been able to create, at massacres, at genocides, etc. This is essentially based on this type of mechanism, so for me it is essential to deconstruct this type of look.

EG: How do you perceive this tension, this rise of populism and nationalism? l'm thinking in particular of the AFD in Germany, which is the last straw in the sense that we didn't think it could happen in that country.
EL: It is very worrying. That is why we must try to deconstruct the views. We must try to stand up against it. But not as a wall, that is not the solution. Because people will end up hitting it and breaking it. So rather, you have to insinuate yourself and try not to convince them, but rather to invite them to ask themselves questions. For example, I put my work on refugees in parallel with that of the Kurdish fighters. There is a gap of eight years between the two. What interests me is that on the one hand, these fighters are like heroes by almost everyone in the West, regardless of their political affiliation. People who reject refugees also idealize these Kurdish fighters; they are the ones who fought Daesh. Except that in my project, it is precisely these same fighters, these people that you find, eight years later, who have become refugees. Now there is a whole section of the population that considers refugees as pariahs, as 
Borders in Globalization Review | Volume 2 | Issue 2 | Spring/Summer 2021

Ganivet, "Borders \& Personal Mythologies: An Interview with Emeric Lhuisset"

parasites, even though they put as heroes these Kurdish fighters. But how can you treat a person like a hero and once he has crossed the sea, consider him like a pariah, a parasite? People don't necessarily make this connection right away. By confronting them with this, doubts, cracks in their rhetoric, their ideology, will be created. It is a question of cracking these ideologies in order to make them collapse. At least that's the way I try to do it. This is obvious during public presentations of my work. At Paris-Photo, for example, when I announced that I was going to talk about refugees, I could feel in the eyes of some people that they didn't really want to listen, that they didn't care, that it wasn't their problem. But as I told the individual stories of the refugees, I could see that the eyes of the audience brightened up a bit that something was happening. When the visit was over, they would end up discussing the subject among themselves, coming back to see certain images, etc. These same people who at first thought they were going to follow the tour out of politeness. It's in those moments that you tell yourself that it works. People won't necessarily change their ideology but they will start to ask questions. That's what's essential, to invite people to question.

EG: While these fighters are heroic, when they arrive on a territory in the West, in this case here in France, it is precisely the question of the other, the relationship to Otherness that arises. We have seen the repercussions of the "migratory crisis" in 2015 and again today, those that have led to a retreat of the borders. What to do with this disturbing Other. As you point out, fear and misunderstanding guide, while we need the other. The excuse is often the demographic term, but the need goes far beyond.

EL: In my opinion, it is a fear that has been created by politicians. There is a play on ignorance, on ignorance, in order to support their power. We always arrive at this search for a scapegoat. From time immemorial this search appears. It has been the Jew, the Protestant, the gypsy... the one we don't know or at least know badly. I have worked a lot on Turkey, where the power is based on the very idea of an internal enemy. It is the Armenians, the Assyrians, the Pontic Greeks, the Alevis, the Kurds. You always have to build an enemy from within.

EG: What is frightening is the relay taken by the new technologies where we end up staying in our own clan, without possibilities of crossing. There are fewer bridges between knowledge.

EL: I ask myself many questions about the new technologies. Yes indeed, it facilitates the communication of ideas.

EG: But the framework remains between us, our communities.

EL: Yes, but wasn't that already the case before? For example, I found a book published in France in the 1920s: "The Jewish-German Conspiracy". This kind of book was circulating, being exchanged. Conspiracies have always existed, even before technology. The new technologies just make it possible to accelerate information, as the invention of the printing press did. The real problem, in my opinion, is that in the end those who could work on deconstructing conspiracies do not do so efficiently enough. The recognized media gather accessible information, but very soon there was the alternative of the internet and social networks. This was very quickly taken over by those whose information could not go through the mainstream media. The web served them to spread their ideas, which was not necessarily the case for the majority of the traditional media, which did not need it because they already had their own distribution channels. As a result, they arrived later on a field that had already been taken over by the conspiracists. Of course, raising doubts is quite healthy but the problem is how, how do you question yourself? What is your knowledge of the subject? Who is telling the story? Some conspiracies are extremely complex to unravel because they are solidly constructed, mixing true and false information. Moreover, the conspiracy has something of seducing in the sense that it brings answer to everything whereas sometimes it is also necessary to know how to accept not to know, one cannot have answer to everything! 